International Journal of Advanced Research in Engineering and Technology (IJARET)

Volume 10, Issue 4, July - August 2019, pp. 72-85, Article ID: IJARET_10_04_009

Available online at http://iaeme.com/Home/issue/IJARET? Volume $=10 \& I s s u e=4$

ISSN Print: 0976-6480 and ISSN Online: 0976-6499

(C) IAEME Publication

\title{
QUALITY CONTROL OF SURFACE WATER QUALITY: A CASE STUDY OF THE LAKE ALEG IN MAURITANIA
}

Yahya Maham Ould Sidi *

GEOPAC Center (GEOPHYSICS, NATURAL PATRIMONY AND GREEN CHEMISTRY), Laboratory Geo Biodiversity National Heritage (LGBPN), Scientific Institute, Mohammed V University of Rabat. Av Ibn Batouta, PO 703, 10106 Rabat -

Morocco,

Laboratory of the Water, Pollution and Environment Unit, Al-Aassriya University of

Nouakchott, Sciences and technologies Faculty, 880 Nouakchott, Mauritanie.

\section{Mohamed Fekhaoui}

GEOPAC Center (GEOPHYSICS, NATURAL PATRIMONY AND GREEN

CHEMISTRY), Laboratory Geo Biodiversity National Heritage (LGBPN), Scientific Institute, Mohammed V University of Rabat. Av Ibn Batouta, PO 703, 10106 Rabat -

Morocco,

\section{M.M.O.Abidine}

Laboratory of the Water, Pollution and Environment Unit, Al-Aassriya University of

Nouakchott, Sciences and technologies Faculty, 880 Nouakchott, Mauritanie.

\section{Abdlekbir Bellaouchou}

GEOPAC Center (GEOPHYSICS, NATURAL PATRIMONY AND GREEN CHEMISTRY), Laboratory Geo Biodiversity National Heritage (LGBPN), Scientific Institute, Mohammed V University of Rabat. Av Ibn Batouta, PO 703, 10106 Rabat -

Morocco,

\section{M.S. kankou and Brahim Ahmed Dick}

Laboratory of the Water, Pollution and Environment Unit, Al-Aassriya University of Nouakchott, Sciences and technologies Faculty, 880 Nouakchott, Mauritanie.

*Correspondence author

\begin{abstract}
Water quality observation data were collected from 10 representative monitoring sites located in the main stream of the Aleg's lake, Mauritania and its major tributaries between 2016 and 2018.
\end{abstract}


The Brakna region (Aleg, Mauritania) is symptomatic to the general State of the Mauritanian Sahel, which was hit by a desertification that has been steadily increasing over the last decades. It results in a strong reduction, or even a local loss, of the potential agro-sylvo-pastoral production, leading to a genuine risk for the populations' survival or at least an aggravation of poverty. All this has not been without impact on a highly deteriorated environment and a lastingly mortgaged socio-economic development. In the light of this situation, we will be studying the hydrochemistry of the surface water of Aleg's lake in Mauritania. After many years of domestic exploitation, both industrial and agricultural, besides climate change, it is interesting to ensure water's quality. With this intention, we have tried to realise a physicochemical analysis, an evaluation, to have an idea on the evolution of the chamical facies of Aleg's lake's water.

For this, a sampling has been done for both dry seasons and wintering of the year 2017 at the 10 stations on both of the lake's shores. The following physicochemical parameters are: $\mathrm{T}, \mathrm{pH}, \mathrm{C} . \mathrm{E}, \mathrm{Ca}^{2+}, \mathrm{Mg}^{2+}, \mathrm{Na}^{+}, \mathrm{K}^{+}, \mathrm{Cl}^{-}, \mathrm{HCO}^{-}$and $\mathrm{SO} 4^{-2}$. These measures include the volumetric and the spectroscopic analyses.

The statistical exploitation of the results and their comparison with the interpretation of Piper's diagram, the results of the present study have shown that the lake's water in general has a bicarbonate calcic and magnesian facies for water at all sampling stations.

As well as the evaluation of the analysis of the physicochemical parameters of the water of Aleg's lake presented in this work, it showed that the $\mathrm{pH}$ is close to neutrality: 7.43 , the mineralization is average due to the conductivity presenting and average of $313.5 \mu \mathrm{S} / \mathrm{cm}$. the average values of the calcium, magnesium, sodium and potassium ions are, respectively, $28.75 \mathrm{mg} / \mathrm{L}, 21 \mathrm{mg} / \mathrm{L}, 28.92 \mathrm{mg} / \mathrm{L}$ and $18.54 \mathrm{mg} / \mathrm{L}$ and the sulphate contents of the samples are very low: $22.13 \mathrm{mg} / \mathrm{L}$. these results meet the FAO norms.

Keywords: Water quality, Hydrochimy, Piper's Diagram, Standards, Irrigation, the Aleg's lake, Mauritania.

Cite this Article: Yahya Maham Ould Sidi , Mohamed Fekhaoui, M.M.O.Abidine, Abdlekbir Bellaouchou, M.S. kankou and Brahim Ahmed Dick, Quality Control of Surface Water Quality: A Case Study of the Lake Aleg in Mauritania. International Journal of Advanced Research in Engineering and Technology, 10(4), 2019, pp. 72-85

http://iaeme.com/Home/issue/IJARET?Volume=10\&Issue $=4$

\section{INTRODUCTION}

Water resources play an important role in the development of different sectors in any country. The surface water is likely to be used as drinking and irrigation water [1]. It is the case of Aleg's lake which plays an important role as a primary source of surface water in Mauritania. Moreover, the lake is Aleg city's drinking and irrigation water's supply source in several villages in the zone of Brakna [2].

In this country, where the climate $\mathrm{s}$ arid and dry, a water resource management seems necessary. In fact, with low rainfall, the geologic nature of the country and the high evaporation rate make the country lacking resource water. Aleg's lake, located in the Brakna region in the south-west of Mauritania, is characterised by a hot climate (annual average temperature greater than $35^{\circ} \mathrm{C}$ ) of Saharo-Sahelian type with a hot season that lasts 8 months 
(from November to June) [3]. The wintering, or rainy season, that follows generally lasts four months, with a peak in pluviometry in August (250-400 mm of rain/year).

The filling dynamic of Aleg's lake depends directly for the main part on the occasional flows of Oued Ketchi, the most important endorheic waterway in the region of Brakna. These flows only happen during the rainy season from July to October. The water finishes its course in the lake, which is a shallow depression [4].

Aleg's lake's surface area of water varies between 0 and $60 \mathrm{~km} 2$ (south-west of Mauritania, Brakna region). Located in an arid region, the lake is a fragile wetland. Il is currently subjected to a significant demographic pressure due to the arrival of the nomads, victims of the increasing drought of the Sahel. The study of this zone's hydraulic operating is currently in the making, in order to reach a relative stability of the lake's water level [5].

Currently and since many years, this vital river has been exposed to some constraints that threaten its physical, chemical and metallic qualities. With diverse geographical pints, this leak receives the releases of domestic waste water [6].

The objective of this study is to evaluate the physicochemical qualities of Aleg's lake's water in Mauritania by the chemical facies of the seasonal surveillance.

\section{ENVIRONMENTAL STUDY}

\subsection{PRESENTATION OF THE STUDIED AREA}

The Islamic Republic of Mauritania's surface area is 1025520 kilometres square, and its position is between latitudes 15 and 27e north. It is bordering Algeria (463 km), Morocco (1 $561 \mathrm{~km})$, Mali $(2237 \mathrm{~km})$ and Senegal. It is bordered on the west by the Atlantic Ocean (700 km) (Fig 1).

The prefecture of Brakna has 240000 inhabitants, namely $10 \%$ of the national population established in five administrative departments covering 3\% of the national territory. This population is at most $95 \%$ of settled people. If the departments of Aleg and Magta-Iahjar have the lowest densities (bigger surface areas), the populations are mostly gathered around Aleg's lake [7]. Aleg is colonial city that was created at the beginning of the XXth century (1903-1904) and that has become the administrative centre of the region of Brakna. This administrative rank bestows upon it an equipment level that is high for a Mauritanian city of approximately 7000 inhabitants. The region's economic activity is essentially geared towards agriculture which generates a local craft (small shops of all types, markets, ovine and caprine fair, etc.) [8]. The city also has a commercial activity that is favoured by its position on the Hope Road, a paved road that allowed the opening up of Mauritania's southern regions and that connects the capital Nouakchott to Nema.

Aleg's lake, located in the Brakna region in the south-west of Mauritania, is characterised by a hot climate (annual average temperature greater than $35^{\circ} \mathrm{C}$ ) of Saharo-Sahelian type with a hot season that lasts 8 months (from November to June) [9]. The wintering, or rainy season, that follows generally lasts four months, with a peak in pluviometry in August. The filling dynamic of Aleg's lake depends directly for the main part on the occasional flows of Oued Ketchi, the most important endorheic waterway in the region of Brakna. These flows only happen during the rainy season from July to October. The water finishes its course in the lake, which is a shallow depression [10]. Aleg's lake's surface area of water varies between 0 and $60 \mathrm{~km} 2$ (south-west of Mauritania, Brakna region). Located in an arid region, the lake is a fragile wetland. Il is currently subjected to a significant demographic pressure due to the arrival of the nomads, victims of the increasing drought of the Sahel. The study of this zone's 
Yahya Maham Ould Sidi, Mohamed Fekhaoui, M.M.O.Abidine, Abdlekbir Bellaouchou, M.S. kankou and Brahim Ahmed Dick

hydraulic operating is currently in the making, in order to reach a relative stability of the lake's water level [11].

In our study, we have chosen as a site the lake area of the river, precisely the Mauritanian city Aleg for many reasons. It is the most dynamic city of the zone and the studied environment receives the domestic discharges and industrial waste.

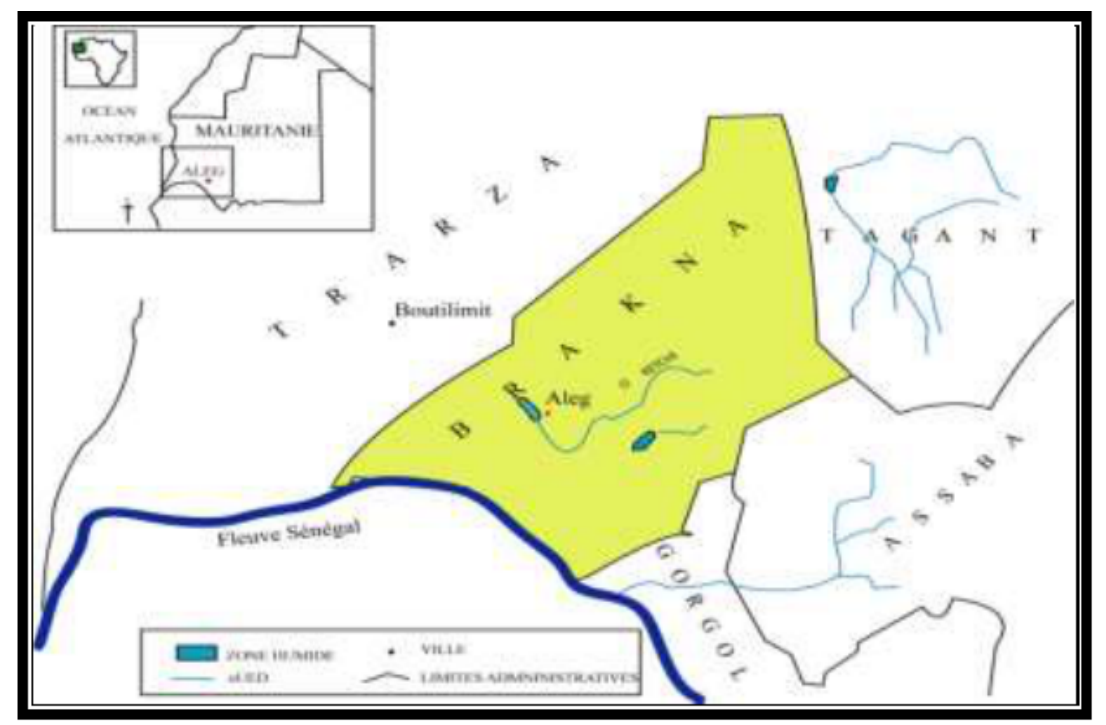

Figure 1: Localization of the study area in Mauritania. Aleg's wetland situation in the regional context of the Mauritanian south-west [12].

\section{MATERIALS AND METHODS}

\subsection{CHOICE OF SAMPLING LOCATIONS}

This study was conducted at the Lake dleg in the Brakna region, south-west of Mauritania. This zone extends between $17^{\circ} 09^{\prime} 30^{\prime \prime} \mathrm{N}, 14^{\circ} 02^{\prime} 05^{\prime \prime} \mathrm{W}$ and $17^{\circ} 02^{\prime} 30^{\prime \prime} \mathrm{N}$ and $13^{\circ} 57^{\prime} 12^{\prime \prime} \mathrm{W}$. It covers an area of $0 \mathrm{~km} 2$. [13] (Fig.2)

In order to evaluate the quality of the lake's water, we have chosen ten sampling stations located on both of the lake's shores. These stations have been selected on the basis of their accessibility, proximity and in accordance with the agricultural and pastoral activities. Pollution sources and their geographical distribution is as follows (Table1):

Table 1: Sampling of the water of Aleg's lake in Mauritania

\begin{tabular}{|c|c|c|c|c|}
\hline \multirow{2}{*}{ Local name } & Abreviations & \multirow{2}{*}{$\begin{array}{c}\text { Water Code } \\
\text { Station numbers in Aleg }\end{array}$} & \multicolumn{2}{|c|}{ GPS Coordinates } \\
\cline { 5 - 5 } & & 01 & 613227 & 1887411 \\
\hline Mechraa & Aleg1 & 02 & 611481 & 1889442 \\
\hline Akreraye & Aleg2 & 03 & 608175 & 1892163 \\
\hline Mechraa veived & Aleg3 & 04 & 605451 & 1895255 \\
\hline Dwalek & Aleg4 & 05 & 602155 & 1896292 \\
\hline Mechraa elbel & Aleg5 & 06 & 600797 & 1894442 \\
\hline Engabe & Aleg6 & 07 & 602754 & 1892872 \\
\hline Mechraa Levreiwatt1 & Aleg7 & 08 & 605703 & 1890386 \\
\hline Mechraa Levreiwatt2 & Aleg8 & 09 & 608881 & 1887981 \\
\hline Mechraa Lehjare & Aleg9 & 10 & 611045 & 1885859 \\
\hline Avreiraye & Aleg10 & & &
\end{tabular}




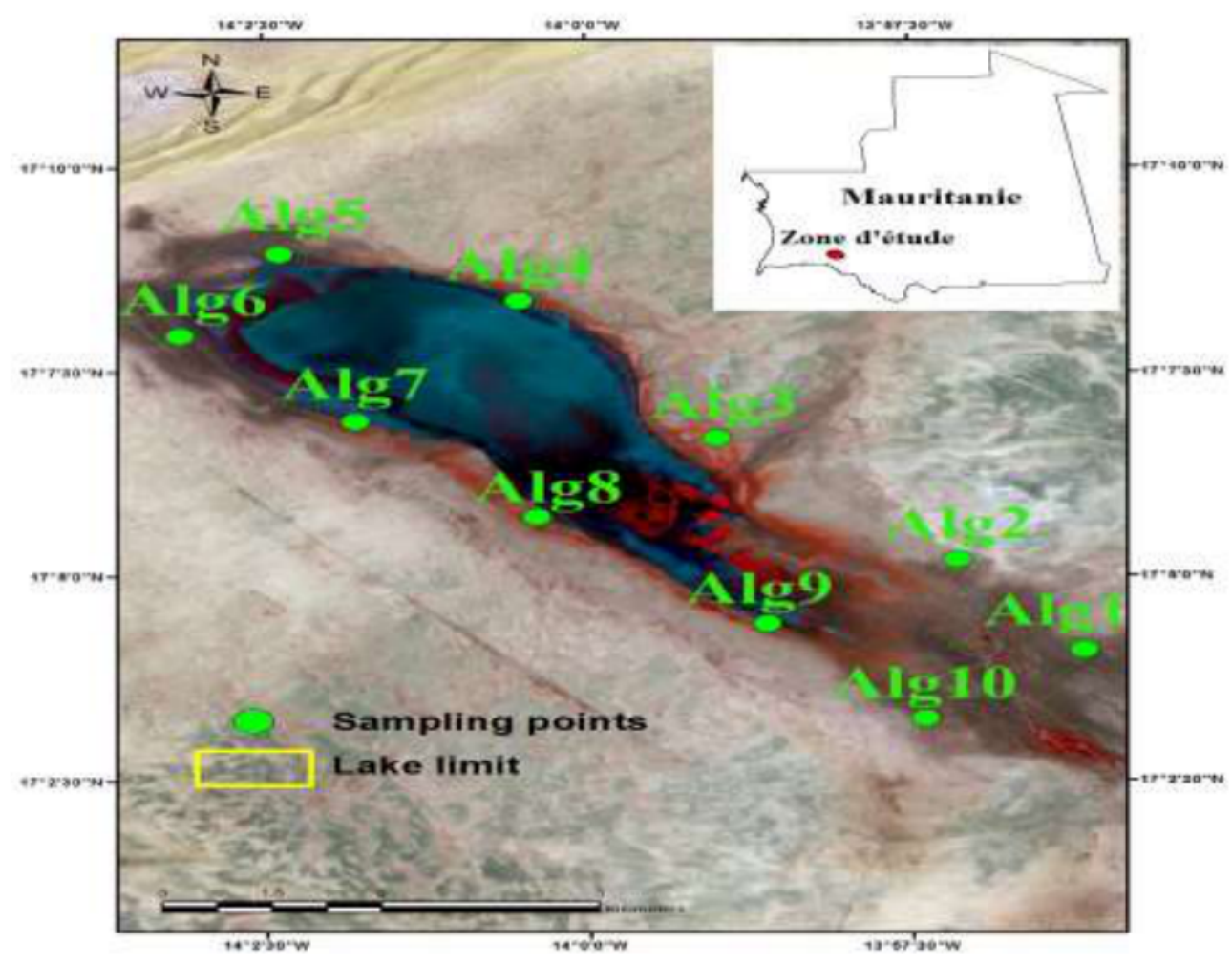

Figure 2: Study area and Water sampling Stations in the study area located in the Lake Aleg southwest of Mauritania [14]

\subsection{SAMPLING}

\subsubsection{Methods of Analysis:-}

The sampling of the water of Aleg's lake has been done in February 2017 for the dry season and in August 2017 for the wintering season[15].

These samplings have been done in clean plastic bottles of 1 litre that have been rinsed beforehand with the taken water, totally immersed in the river water and they are hermetically filled in order to avoid any contamination (Photo 1) [16].

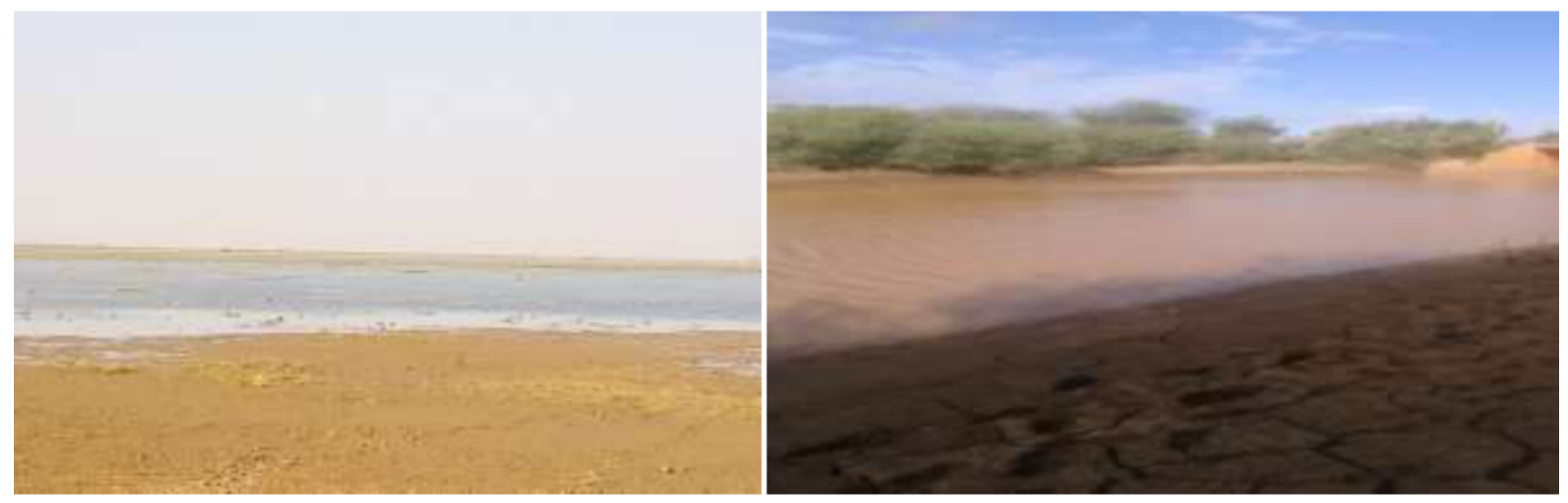

Photo1: Scenery of the zone of Aleg's lake in Mauritania, February, August 2017 
Yahya Maham Ould Sidi, Mohamed Fekhaoui, M.M.O.Abidine, Abdlekbir Bellaouchou, M.S. kankou and Brahim Ahmed Dick

\subsection{ANALYSIS METHODS}

At the same time as taking the test sample of water, we have proceeded to measuring the temperature of the water and the $\mathrm{pH}$ is measured using a $\mathrm{pH}$ measures portable of brand HANNA series 9,024. The electric conductivity (E.C.) has been measured, using a conductivity meter of type HANNA instrument HI 8733. The Sulphates (SO42-) are dosedusing a UV- Visible Spectrophotometer (WEG 7100).

The Sodium $(\mathrm{Na}+)$ and Potassium $(\mathrm{K}+)$ alkaline metals are dosed using a flame photometer. Calcium $(\mathrm{Ca} 2+)$, magnesium $(\mathrm{Mg} 2+)$, chloride $(\mathrm{Cl}-)$ and bicarbonates $(\mathrm{HCO} 3-)$ are dosed by volumetric methods of Mohr in the presence of the selective mediums (Rodier, 1996).

The analyses were carried out within the research unit Water-pollution and Environment at the University of Nouakchott Al- Aassriya[17].

\section{RESULTS AND DISCUSSION}

These results are exploited by the statistical analysis and their comparison to the interpretation of Piper's diagram.

The physicochemical quality of the raw water of Aleg's lake in Mauritania has been monitored through the analysis of the water taken from ten (10) sites. for both seasons dry season (Table 2) and rainy season (Table.3)

\subsection{PARAMETERS' EVOLUTION}

Table2: Physicochemical results dry season February (2017) average results of water parameters

\begin{tabular}{|c|c|c|c|c|c|c|c|c|c|c|c|}
\hline $\begin{array}{c}\text { Code } \\
\text { Station numbers in } \\
\text { Aleg }\end{array}$ & \multirow{2}{*}{$\mathrm{PH}$} & $\mathrm{T}$ & $\mathrm{Cond}$. & $\mathrm{Cl}-$ & $\mathrm{HCO}-$ & $\mathrm{Ca} 2+$ & $\mathrm{Mg} 2+$ & $\mathrm{Na}+$ & $\mathrm{K}+$ & $\mathrm{NO}-3$ & $\begin{array}{c}\mathrm{SO}- \\
4\end{array}$ \\
\cline { 2 - 13 } & & $\left({ }^{\circ} \mathrm{C}\right)$ & $\mu \mathrm{s} / \mathrm{cm}$ & $(\mathrm{mg} / \mathrm{l})$ & $(\mathrm{mg} / \mathrm{l})$ & $(\mathrm{mg} / \mathrm{l})$ & $(\mathrm{mg} / \mathrm{l})$ & $\begin{array}{c}(\mathrm{mg} / \\
1)\end{array}$ & $\begin{array}{c}(\mathrm{mg} \\
/ 1)\end{array}$ & $(\mathrm{mg} / \mathrm{l})$ & $(\mathrm{mg} / \mathrm{l})$ \\
\hline Alg 01 & 7,02 & 20 & 518 & 35,5 & 320,25 & 40,08 & 26,244 & 32 & 24 & 12,6 & 58 \\
\hline Alg 02 & 7,14 & 23 & 444 & 28,4 & 259,25 & 46,49 & 30,618 & 29 & 22 & 10 & 61 \\
\hline Alg 03 & 7,3 & 23,5 & 339 & 31,95 & 198,25 & 28,05 & 21,87 & 25 & 20 & 9 & 27 \\
\hline Alg 04 & 7,52 & 24 & 382 & 17,75 & 189,1 & 34,47 & 34,506 & 26 & 20 & 15 & 22 \\
\hline Alg 05 & 7,42 & 24 & 393 & 24,85 & 231,8 & 33,67 & 19,44 & 26 & 20 & 11,8 & 51 \\
\hline Alg 06 & 7,55 & 24 & 364 & 24,85 & 195,2 & 16,03 & 24,786 & 27 & 25 & 6 & 21 \\
\hline Alg 07 & 7,51 & 23 & 410 & 46,15 & 207,4 & 33,67 & 23,328 & 31 & 26 & 8 & 9 \\
\hline Alg 08 & 7,56 & 23,6 & 624 & 78,1 & 341,6 & 54,5 & 44,712 & 46 & 31 & 13,8 & 10 \\
\hline Alg 09 & 7,6 & 24 & 346 & 24,85 & 189,1 & 29,66 & 20,898 & 27 & 21 & 3,8 & 14 \\
\hline Alg 10 & 7,62 & 23,7 & 702 & 102,95 & 274,5 & 40,88 & 45,198 & 51 & 35 & 5,4 & 10 \\
\hline Maximum & 7,62 & 24 & 702 & 102,95 & 341,6 & 54,5 & 45,198 & 51 & 35 & 15 & 61 \\
\hline Minimum & 7,02 & 20 & 339 & 17,75 & 189,1 & 16,03 & 19,44 & 25 & 20 & 3,8 & 9 \\
\hline Average & 7,424 & 23,28 & 452,2 & 41,535 & 244,76 & 35,75 & 29,16 & 32 & 24 & 9,54 & 28,3 \\
\hline
\end{tabular}


Quality Control of Surface Water Quality: A Case Study of the Lake Aleg in Mauritania

Table 3: Physicochemical results wintering season August (2017) average results of water parameters

\begin{tabular}{|c|c|c|c|c|c|c|c|c|c|c|c|}
\hline $\begin{array}{c}\text { Code } \\
\begin{array}{c}\text { Station } \\
\text { numbers in } \\
\text { Aleg }\end{array}\end{array}$ & $\mathrm{pH}$ & $\mathrm{T}$ & $\mathrm{Cond}$. & $\mathrm{Cl}^{-}$ & $\mathrm{HCO}^{-}$ & $\mathrm{Ca}^{+}$ & $\mathrm{Mg}^{+}$ & $\mathrm{Na}^{+}$ & $\mathrm{K}^{+}$ & $\mathrm{NO}^{-}$ & $\mathrm{SO}^{-2}$ \\
\hline Alg 01 & 7,15 & 30,3 & 101 & 10,65 & 54,9 & 14,4 & 10,2 & 20 & 14 & 0,52 & 41 \\
\hline Alg 02 & 7,2 & 30,2 & 107 & 10,65 & 42,7 & 18,43 & 5,83 & 14 & 12 & 0,54 & 19 \\
\hline Alg 03 & 7,29 & 30,3 & 109 & 17,75 & 97,6 & 32,86 & 13,6 & 12 & 9 & 2 & 10 \\
\hline Alg 04 & 7,5 & 30,3 & 257 & 28,4 & 103,7 & 32,8 & 16,52 & 13 & 9 & 0,38 & 5 \\
\hline Alg 05 & 7,48 & 30,2 & 259 & 14,2 & 103,7 & 16,8 & 16,03 & 13 & 9 & 0,74 & 1 \\
\hline Alg 06 & 7,55 & 30,2 & 182 & 10,65 & 91,5 & 18,43 & 17,49 & 13 & 15 & 0,2 & 1 \\
\hline Alg 07 & 7,63 & 30,1 & 220 & 17,75 & 73,2 & 24,84 & 11,66 & 15 & 15 & 0,3 & 20 \\
\hline Alg 08 & 7,6 & 30,3 & 220 & 17,75 & 115,9 & 28,05 & 13,12 & 25 & 18 & 0,54 & 2 \\
\hline Alg 09 & 7,64 & 30,2 & 187 & 14,2 & 48,8 & 18,43 & 11,17 & 13 & 12 & 0,54 & 2 \\
\hline Alg 10 & 7,65 & 30,2 & 67 & 7,1 & 36,6 & 10,42 & 6,8 & 26 & 10 & 0,52 & 36 \\
\hline Maximum & 7,15 & 30,1 & 67 & 7,1 & 36,6 & 10,42 & 5,83 & 12 & 9 & 0,2 & 1 \\
\hline Minimum & 7,65 & 30,3 & 259 & 28,4 & 115,9 & 32,86 & 17,49 & 26 & 18 & 2 & 41 \\
\hline Average & 7,46 & 30,23 & 169,58 & 15,38 & 76,76 & 21,56 & 12,15 & 16,83 & 12,5 & 0,71 & 14,92 \\
\hline
\end{tabular}

Table 4: Physicochemical results annual (2017) average results of water parameters

\begin{tabular}{|c|c|c|c|c|c|c|c|}
\hline \multirow[b]{2}{*}{ Parameters } & \multirow[b]{2}{*}{ Unit } & \multirow[b]{2}{*}{ Minimum } & \multirow[b]{2}{*}{ Maximum } & \multirow[b]{2}{*}{ Average } & \multicolumn{3}{|c|}{ FAO $1979[6]}$. \\
\hline & & & & & $\begin{array}{c}\text { Not of } \\
\text { problems }\end{array}$ & $\begin{array}{c}\text { Increasing } \\
\text { problems }\end{array}$ & $\begin{array}{c}\text { serious } \\
\text { problems }\end{array}$ \\
\hline $\mathrm{pH}$ & & 7,09 & 7,64 & 7,43 & $6.5-8.4$ & & \\
\hline $\mathrm{T}$ & ${ }^{\circ} \mathrm{C}$ & 25,15 & 27,15 & 26,76 & & - & \\
\hline $\mathrm{CE}$ & $\mu \mathrm{s} / \mathrm{cm}$ & 224 & 422 & 313,46 & $<750$ & $750-2000$ & $>3000$ \\
\hline $\mathrm{Ca}^{2+}$ & $\mathrm{mg} / \mathrm{l}$ & 41,28 & 17,23 & 28,75 & - & - & - \\
\hline $\mathrm{Mg}^{2+}$ & $\mathrm{mg} / 1$ & 28,92 & 16,03 & 21,48 & - & - & - \\
\hline $\mathrm{Na}^{+}$ & $\mathrm{mg} / \mathrm{l}$ & 38,5 & 18,5 & 24,92 & - & - & - \\
\hline $\mathrm{K}^{+}$ & $\mathrm{mg} / \mathrm{l}$ & 24,5 & 14,5 & 18,54 & - & - & - \\
\hline $\mathrm{HCO}^{-}$ & $\mathrm{mg} / \mathrm{l}$ & 228,75 & 118,95 & 161,27 & $<91.5$ & $91.5-518.5$ & $>518.5$ \\
\hline $\mathrm{NO}^{-}$ & $\mathrm{mg} / \mathrm{l}$ & 2,7 & 7,69 & 5,09 & $<5$ & $5.0-30$ & $>30$ \\
\hline $\mathrm{Cl}^{-}$ & $\mathrm{mg} / 1$ & 55,025 & 17,75 & 29,58 & $<142$ & $142-355$ & $>355$ \\
\hline $\mathrm{SO}_{4}^{-2}$ & $\mathrm{mg} / 1$ & 49 & 6 & 22,13 & & & \\
\hline
\end{tabular}


Yahya Maham Ould Sidi, Mohamed Fekhaoui, M.M.O.Abidine, Abdlekbir Bellaouchou, M.S. kankou and Brahim Ahmed Dick

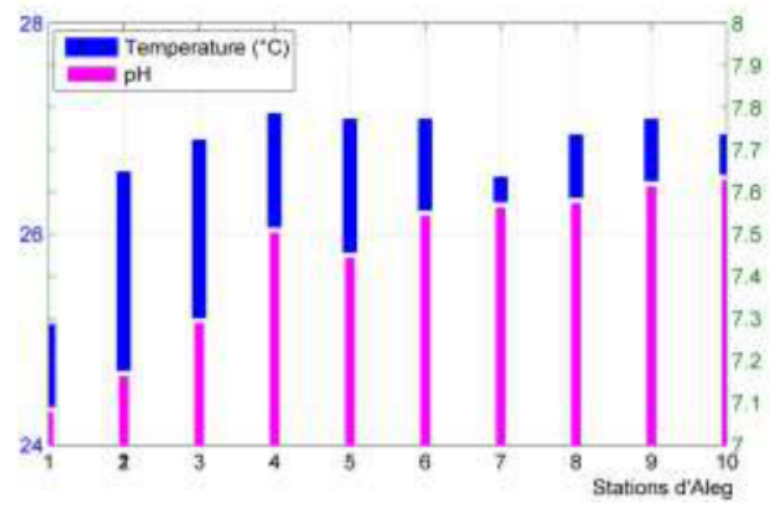

Figure 3: Annual variations of the $\mathrm{pH}$ and temperature

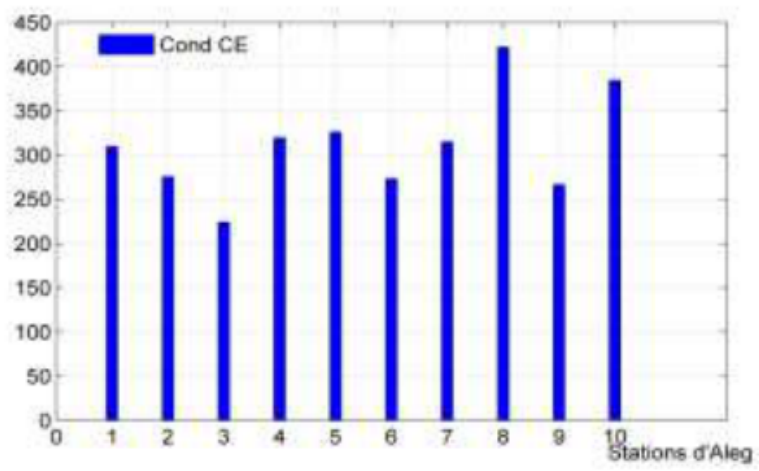

Figure 4: Spatial variations of the electric conductivity E.C. in $(\mu \mathrm{S} / \mathrm{cm})$

The analyses carried out show that the annual average temperature of the samples is between $25^{\circ} \mathrm{C}$ and $27^{\circ} \mathrm{C}$ (Fig 3). Their pH as well is between 7.09 and 7.64 and is within the normal range (from 6.5 to 8.4 ) according to the FAO directives (Fig 3). Concerning the mineralisation of the lake's raw water, the measures of the annual average conductivity of the all the samples show that they are between $224 \mu \mathrm{S} / \mathrm{cm}$ and $422 \mu \mathrm{S} / \mathrm{cm}$ (Fig 4), and lower than the grid $(750 \mu \mathrm{S} / \mathrm{cm})$, the water is indexed in the "Not of Problems" category. Thus, no permeability problem that is linked to the total salinity is to be considered (Table 4).

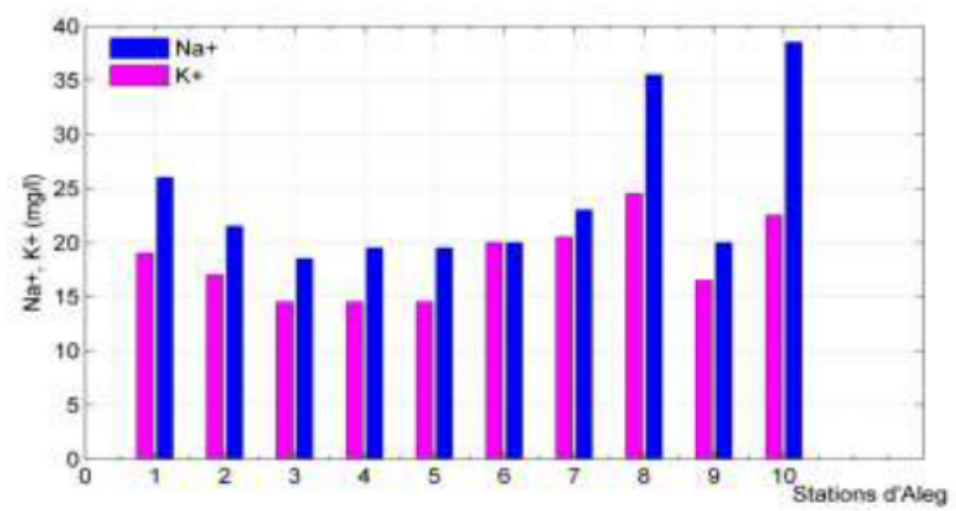

Figure 5: Spatial variations of Sodium $\left(\mathrm{Na}^{+}\right)$and Potassium $\left(\mathrm{K}^{+}\right)$ 


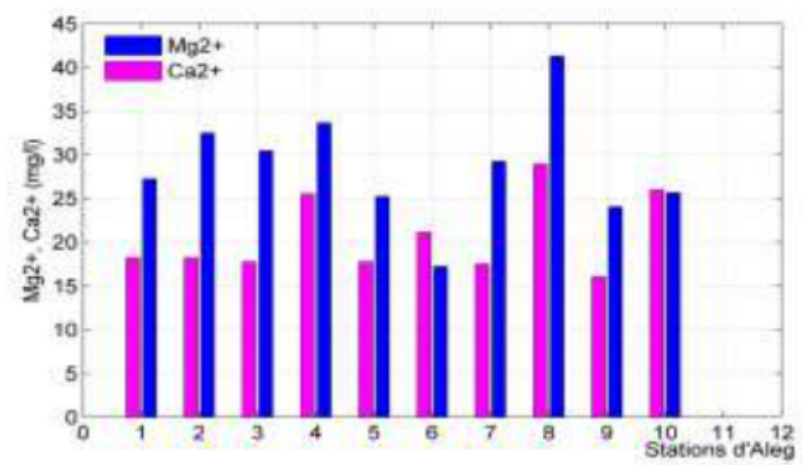

Figure 6: Spatial variations of Calcium $\left(\mathrm{Ca}^{2+}\right)$ and Magnesium $\left(\mathrm{Mg}^{2+}\right)$.

The annual average contents of Sodium and Potassium in the samples vary respectively from $18,5 \mathrm{mg} / \mathrm{L}$ to $38,5 \mathrm{mg} / \mathrm{L}$ and from $14,5 \mathrm{mg} / \mathrm{L}$ to $24,5 \mathrm{mg} / \mathrm{L}$ (Fig 5). The annual average contents in Calcium and Magnesium vary respectively from $17,23 \mathrm{mg} / \mathrm{L}$ to $41,28 \mathrm{mg} / \mathrm{L}$ and from $16,03 \mathrm{mg} / \mathrm{L}$ to $28,92 \mathrm{mg} / \mathrm{L}$ (Fig 6).

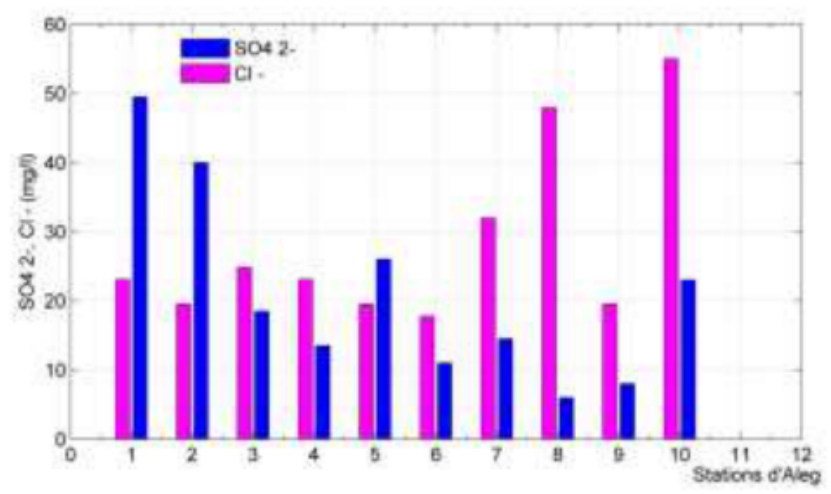

Figure 7: Spatial variations of Chloride $(\mathrm{Cl})$ and Sulphate $\left(\mathrm{SO} 4^{2-}\right)$

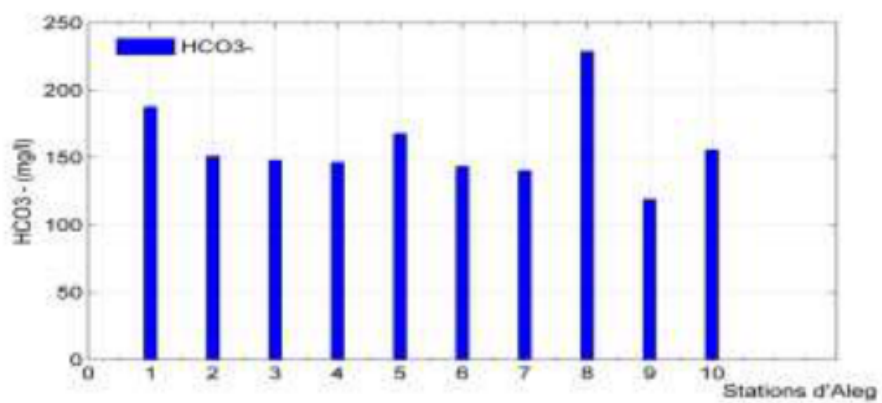

Figure 8: Spatial variations of Bicarbonates $\left(\mathrm{HCO}^{-}\right)$

The average annual contents in Chloride and Bicarbonates vary respectively from 17.75 $\mathrm{mg} / \mathrm{L}$ to $55.025 \mathrm{mg} / \mathrm{L}$ and from $118.95 \mathrm{mg} / \mathrm{L}$ and $228.75 \mathrm{mg} / \mathrm{L}$ (Fig7). The contents in Sulphate of the samples vary between $6 \mathrm{mg} / \mathrm{L}$ and $49 \mathrm{mg} / \mathrm{L}$ (Fig8).

\subsection{EVALUATION OF PIPER'S DIAGRAM}

Piper's diagram is particularly adapted to the study of the study of the water's facies when the mineralisation increases (Andreu et al, 2010), [18]; or else to compare the groups of samples in between them and indicate the types of the dominant cations and anions, by usinga descriptive and compared approach which allows to represent, on the same graphic, a big 
number of monitoring stations allowing a classification by families presenting similar facies. The waters of Aleg's lake have a low mineralisation so their presentation on Piper's diagram will use the simulation and comparison of the waters, spatially and periodically, in order to know the dominant chemical facies in every station and every climatic season. The global presentation of the physicochemical analysis' results, in all stations and at all periods, indicate the presence of different chemical facies (Fig 9) [19].

\subsubsection{Piper's Diagram for the dry season}

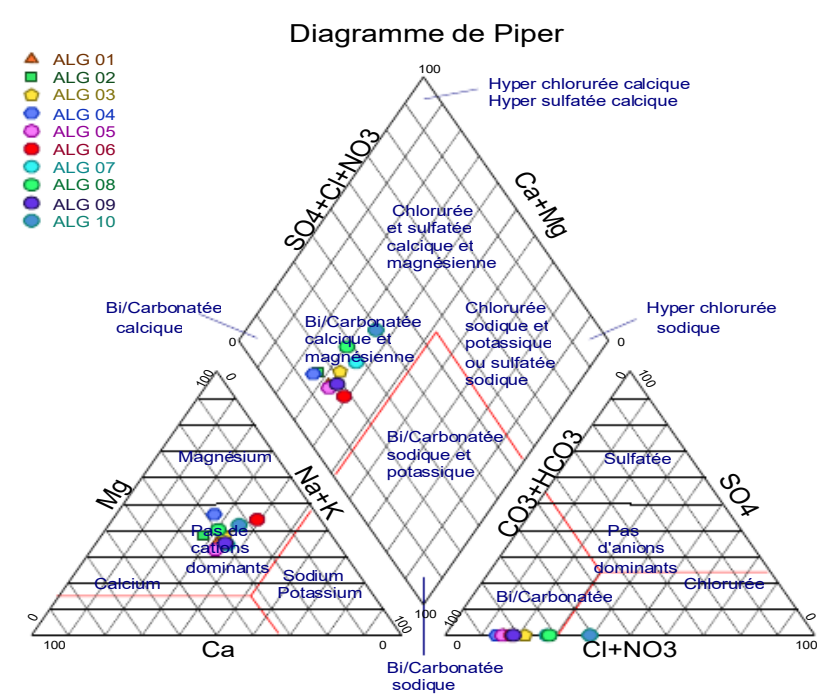

Figure.9: Piper's Diagram for the dry season analysis of water in Aleg's lake (Aleg, Mauritania)

The interpretation of Piper's diagram's graphic representation for the physicochemical results in the studied climatic dry season (Fig 9) allows us to divide water in Aleg's lake (Aleg, Mauritania) into two chemical facies:

A Calcic and Magnesian Bicarbonate facies

$>$ A Bicarbonate facies

$>$ Without dominant cations for the cations' triangle

\subsubsection{Piper's Diagram for the wintering season}

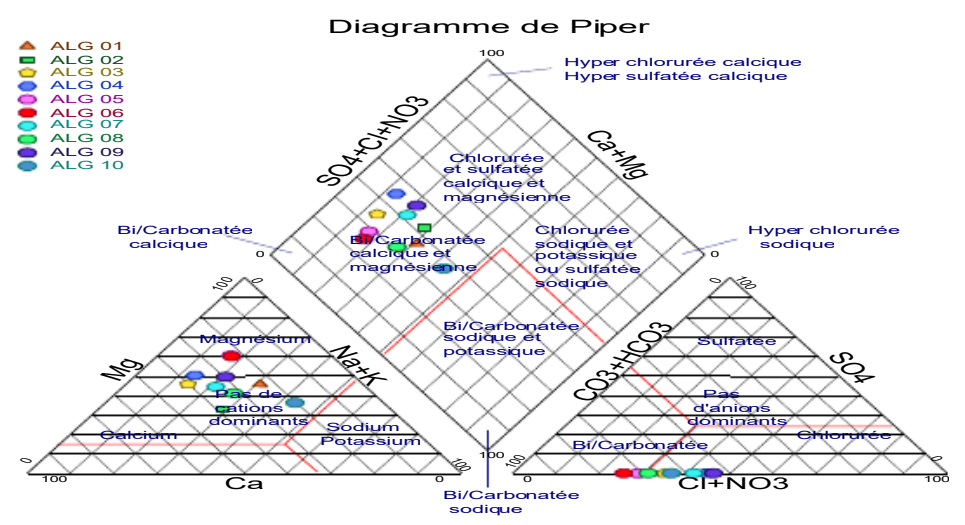

Figure.10 : Piper's Diagram for the wintering season analysis of water in Aleg's lake (Aleg, Mauritania) 
The interpretation of Piper's diagram's graphic representation for the physicochemical results in the studied wintering season (Fig 10) allows us to divide water in Aleg's lake (Aleg, Mauritania) into two chemical facies:

$>$ A Calcic and Magnesian Bicarbonate facies

$>$ A Bicarbonate Chloride facies

$>$ Without dominant cations for the cations' triangle

\subsubsection{Piper's Diagram of the annual average analysis of waters of Aleg's lake}

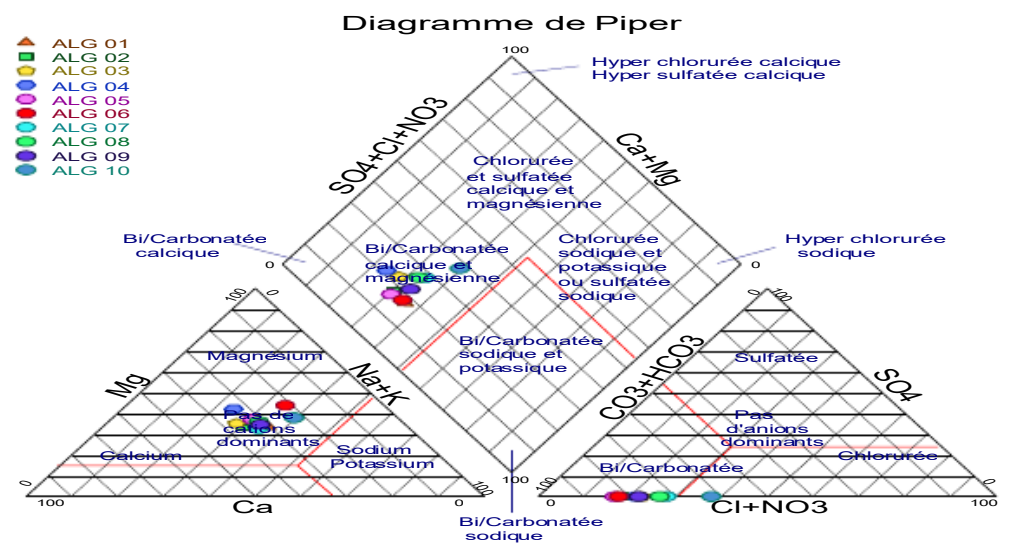

Figure.11: Piper's Diagram of the annual average analysis of waters of Aleg's lake (Aleg, Mauritania)

To get an idea on these facies, a presentation of the annual average results of the water in stations of (Fig 11) allows us to notice that water in Aleg's lake in general has: a Calcic and Magnesian Bicarbonate facies for water in all sampling stations.

In the context of our study, we have done a total of 10 samplings for the physicochemical analysis. The different samples of raw water in Aleg's lake have been tested in order to be analysed. The samples have been taken in polythene flasks having a capacity of 1 litre.

The electric conductivity translates the degree of global mineralisation, it informs us on the level of salinity [20]. The conductivity measures of the samples show that they are included between $224 \mu \mathrm{S} / \mathrm{cm}$ and $422 \mu \mathrm{S} / \mathrm{cm}$

The Calcium and Magnesium contents vary respectively from $17.23 \mathrm{mg} / \mathrm{L}$ to $41.28 \mathrm{mg} / \mathrm{L}$ and from $16.03 \mathrm{mg} / \mathrm{L}$ to $28.92 \mathrm{mg} / \mathrm{L}$ (Table.2). The Chloride and Carbonates contents vary respectively from $17.75 \mathrm{mg} / \mathrm{L}$ to $55.025 \mathrm{mg} / \mathrm{L}$ and from $118.95 \mathrm{mg} / \mathrm{L}$ to $228.75 \mathrm{mg} / \mathrm{L}$. The Sulphate contents in the samples vary from $6 \mathrm{mg} / \mathrm{L}$ to $49 \mathrm{mg} / \mathrm{L}$ (Table.2).

To get an idea on these facies, a presentation of the annual average results of the water in stations of (Fig.3) allows us to notice that water in Aleg's lake in general has: a Calcic and Magnesian Bicarbonate facies for water in all sampling stations.

\section{CONCLUSION}

The physicochemical parameters collected from superficial water in the lac Aleg in Mauritania vary little from one site to another and do not show an apparent accumulation of metals in the samples analysed.

The results of the physicochemical parameters' analysis of the water in Aleg's lake in Mauritania, presented in this work, used for the irrigation and pastoral work, compared to the 
values norms (FAO) have shown that the water in Aleg's lake is categorised in the category "Not of Problems".

The average values, of the calcium, magnesium, sodium and potassium ions are, respectively, $28.75 \mathrm{mg} / \mathrm{L}, 21,48 \mathrm{mg} / \mathrm{L}, 24,92 \mathrm{mg} / \mathrm{L}$ and $18,54 \mathrm{mg} / \mathrm{L}$ and The Sulphate contents on the samples are very low at $28.3 \mathrm{mg} / \mathrm{L}$, Thereby, all the waters in Aleg's lake in general have: A Calcic and Magnesian Bicarbonate facies for water in all the sampling stations.

\section{ABBREVIATIONS}

Aleg: areas of the BRAKNA region (in the south-west of the Mauritania),EPE: Pollution and Environment Unit, GEOPAC: Center (geophysics, natural patrimony and green chemistry) KETCHI: the largest river that feeds Lake Aleg, WHO :World Health Organization, E.C: is The electric conductivity , Fe: iron; IQR: interquartile range; MDG: Millennium Development Goals, Mn: manganese, NaCl: sodium chloride, WASH: Water, Sanitation and Hygiene, FAO: Food and Agriculture Organization of the united Nations.

\section{COMPETING INTERESTS}

The authors declare that they have no competing interests.

\section{AUTHORS' CONTRIBUTIONS}

LGBPN, GEOPAC, and EPE contributed to the data collection. Conducted the data analysis and participated in the result interpretation. Wrote the manuscript. LGBPN, GEOPAC, and EPE commented on the manuscript draft. All authors read and approved the final manuscript.

\section{ACKNOWLEDGEMENTS}

This study results from a collaboration between the University of Nouakchott Al Aasriya( Mauritania), Scientific Institute, Mohammed V University of Rabat (Morocco),We would like to thank the respondents who provided valuable information and time for this study. We thank all the interviewers involved in the data collection and the field staff for their assistance in conducting this study.

We acknowledge the Data Management EPE Unit for their support in data entry and cleaning. Finally, we acknowledge the Government of the Mauritania for funding the study. We thank the direction of scientific research at the level of our Ministry of Higher Education and Scientific Research of Mauritania (www.mesrs.mr/fr/) for editorial assistance.The reason why a large number of authors (6) contributed to the realization of this manuscript takes place in their specialization as well as their respective roles in the different parts ofthis document.

\section{REFERENCES}

[1] ELGHADI AV, BALLOUCHE A, MOGUEDET G. Elghadi av, ballouche a, moguedet g. diagnostic de la dynamique des ressources hydriques de surface et des processus de «désertification» du lac d'aleg et de son bassin versant (brakna, mauritanie) par télédétection multidate. 2005; 2005. G.

[2] Taïbi AN, Barry M el H, Jolivel M, Ballouche A, Baba MLO, Moguedet G. Enjeux et impacts des barrages de Diama (Mauritanie) et Arzal (France): des contextes socioéconomiques et environnementaux différents pour de mêmes conséquences. Norois. 2007 Jun 1;(203):51-66. 
[3] Qinggai Wang, Shibei Li, Peng Jia, Changjun Qi, and Feng Ding, A Review of Surface Water Quality Models, Hindawi Publishing Corporation The Scientific World Journal Volume 2013, Article ID 231768, 7 pages http://dx.doi.org/10.1155/2013/231768

[4] Sharad Tiwari , 1 Richa Babbar , 2 and Gagandeep Kaur1, Performance Evaluation of Two ANFIS Models for Predicting Water Quality Index of River Satluj (India) Hindawi Advances in Civil Engineering Volume 2018, Article ID 8971079, 10 pages https://doi.org/10.1155/2018/8971079

[5] Ahmed Barakata, Mohamed El Baghdadia, Jamila Raisa, Brahim Aghezzaf, Mohamed Slassib, "Assessment of spatial and seasonal water quality variation of Oum Er Rbia River (Morocco) using multivariate statistical techniques," International Soil and Water Conservation Research Volume 4, Issue 4, December 2016, Pages 284-292.

[6] Kamran Zeinalzadeha, Elnaz Rezaeib, "Determining spatial and temporal changes of surface water quality using principal component analysis," Journal of Hydrology: Regional Studies, Volume 13, October 2017, Pages 1-10.

[7] Simon Ettera, Nans Addora, Matthias Hussc, David Finger, "Climate change impacts on future snow, ice and rain runoff in a Swiss mountain catchment using multi-dataset calibration," Journal of Hydrology: Regional Studies, 13 (2017) 222-239.

[8] Abdulla Umar Naseef. T, Reeba Thomas, Identification of Suitable Sites for Water Harvesting Structures in Kecheri River Basin, Procedia Technology 24 ( 2016 ) 7 - 14.

[9] Abidine MMO, El Aboudi A, Kebd A, Aloueimine BB, Dallahi Y, Soulé A, et al. Modeling the Spatial Variability of the Electrical Conductivity of the Soil Using Differents Spatial Interpolation Methods: Case of the Dawling National Park in Mauritania. Geogr Tech. 2018 Oct 29;13(2):1-11

[10] Alexis B. Nienie, Periyasamy Sivalingam, Amandine Laffite, Patience Ngelinkoto, JeanPaul Otamonga, Alphonse Matand, Crispin K. Mulaji, Josué I. Mubedi, Pius T. Mpiana, John Poté, Seasonal variability of water quality by physicochemical indexes and traceable metals in suburban area in Kikwit, Democratic Republic of the Congo, International Soil and Water Conservation Research, Nienie, A. B., et al. (2017), http://dx.doi.org/10.1016/j.iswcr.2017.04.004i

[11] Meera . G. Mohana and P. G. Jairaj, Comparison of FE and FLS model for Surface water quality Assessment, Procedia Technology, Volume 24, 2016, Pages 77-84.

[12] Gu, H., Yu, Z.Wang, G, Ju, Q, Yang, C, \& Fan, C. (2015). Impact of climate change on hydrological extremes in the Yangtze River Basin, China. Stochastic Environmental Research and Risk Assessment, March 2015, Volume 29, Issue 3, pp 693-707

[13] O.E.Idise, F.J.Okoko, P.Aire, O.Ogor, A.Egbah, The effects of solidwoodwastedischargeon the physico-chemical and microbial characteristicsoftheWarririver, Afr.J.Microbiol.Res.6 (20)(2012)4302-4314.

[14] K.D.Oyeyemi,A.O.Folake, Assessmen to fground water contaminationduetoleachatesfromanopendumpsiteusing resistivityimaging,IndianJ.Environ.Prot.36(9)(2016)734-739

[15] Mohammad HajigholizadehaAssefa M.Melesseb (2017), Assortment and spatiotemporal analysis of surface water quality using cluster and discriminant analyses, CATENA Volume, April 2017, Pages 247-258

[16] Kang Young JungaKyung-LakLeeaToe HyoImaIn Jung LeeaShinKimaKunYeunHanbJung MinAhn (2016), Evaluation of water quality for the Nakdong River watershed using multivariate analysis, Environmental Technology \& InnovationVolume 5, April 2016, Pages 67-82

[17] Guan, B, Wen, H.S, Liu, Q, Wang, J.H, \& Wang, Q.L. The effects of acute temperature stress on blood cells and serum biochemical components in rainbow trout (Oncorhynchus mykiss). (2014) 
Yahya Maham Ould Sidi, Mohamed Fekhaoui, M.M.O.Abidine, Abdlekbir Bellaouchou, M.S.

kankou and Brahim Ahmed Dick

[18] Kamran Zeinalzadeh ElnazRezaei, Determining spatial and temporal changes of surface water quality using principal component analysis, Journal of Hydrology: Regional Studies Volume 13, (2017), 1-10

[19] Adaelson Campelo Medeirosa,c,*, Kleber Raimundo Freitas Faiala, Kelson do Carmo Freitas Faiala,Iris Danielly da Silva Lopesa, Marcelo de Oliveira Limaa, Raphael Mendonça Guimarãesb,Neyson Martins Mendonçac, Quality index of the surface water of Amazonian rivers in industrial areas in Pará, Brazil, Marine Pollution Bulletin 123 (2017) 156-164.

[20] C. K. JainEmail author A. Bandyopadhyay A. Bhadra, Assessment of ground water quality for drinking purpose, District Nainital, Uttarakhand, India, Environmental Monitoring and Assessment July 2010, Volume 166, Issue 1-4, pp 663-676| Cite as

[21] Hamed A. El-Serehy a,b, $\Uparrow$, Hala S. Abdallah c,d, Fahad A. Al-Misned a, Saleh A. AlFarraj a, Khaled A. Al-Rasheid a, Assessing water quality and classifying trophic status for scientifically based managing the water resources of the Lake Timsah, the lake with salinity stratification along the Suez Canal, Saudi Journal of Biological Sciences (2018)

[22] Hang Xie1, Xiao Lü1, Jing Zhou2, Chenchen Shi1, Yongli Li1, Ting Duan1, Ge Li1, Yiping Luo1, Effects of Acute Temperature Change and Temperature Acclimation on the Respiratory Metabolism of the Snakehead, Turkish Journal of Fisheries and Aquatic Sciences 17: 535-542 (2017)

[23] Martin Schönharta, Helene Trautvetterb, Juraj Parajkac, Alfred Paul Blaschkec, Gerold Heppb,Mathias Kirchnera,d, Hermine Mittera, Erwin Schmida, Birgit Strennb, Matthias Zessnerb, Modelled impacts of policies and climate change on land use and water quality in Austria, 76 (2018) 500-514

[24] Boyd, C.E. Water Quality in Ponds for Aquaculture, Auburn, AL: Auburn University. Alabama Agricultural Experiment Station. Pres. Alabama, USA, 1990, 482 pp.

[25] Yalçın Tepe,* Aysun Türkmen, Ekrem Mutlu, Alpaslan Ateú 1 Some Physicochemical Characteristics of Yarseli Lake, Hatay, Turkey, Turkish Journal of Fisheries and Aquatic Sciences 5: 35-42 (2005)

[26] V.S.S.R. Gupta, R. Srinivasa Rao and K. Divya, Evaluation of Groundwater Quality using Multivariate Statistical Techniques and GIS - A Case Study. International Journal of Civil Engineering and Technology, 8(8), 2017, pp. 1165-1176.

[27] SS. Asadi, Ramya.Aduri and Kowmudhi.Bachinappa, Evaluation of Water Quality Role on Environmental Impact Assessment Study. International Journal of Civil Engineering and Technology, 8(3), 2017, pp. 778-784.

[28] Mujiati, M. Saleh Pallu, Mary Selintung and Farouk Maricar, A Study on the Land use Change and its Effect Toward the Water Quality in Kampwolker River. International Journal of Civil Engineering and Technology, 8(7), 2017, pp. 893-901.

[29] Jyotiprakash G. Nayak and Dr. L. G. Patil. Assessment of Water Quality of Godavari River at Nashik, Maharashtra, India. International Journal of Civil Engineering and Technology, 7(1), 2016, pp. 83-92. 